\title{
Impact of the Eastern oyster Crassostrea virginica on microbial community structure in a salt marsh estuary
}

\author{
Michael S. Wetz ${ }^{1, *}$, Alan J. Lewitus ${ }^{2,3}$, Eric T. Koepfler ${ }^{1}$, Kenneth C. Hayes ${ }^{2,4}$ \\ ${ }^{1}$ Coastal Carolina University, Marine Science Department, Conway, South Carolina 29526, USA \\ ${ }^{2}$ Belle W. Baruch Institute for Marine Biology and Coastal Research, University of South Carolina, PO Box 1630, \\ Georgetown, South Carolina 29442, USA \\ ${ }^{3}$ Marine Resources Research Institute, South Carolina Department of Natural Resources, PO Box 12559, Charleston, \\ South Carolina 29422, USA \\ ${ }^{4}$ South Carolina Department of Health and Environmental Control, Columbia, South Carolina 29201, USA
}

\begin{abstract}
In the tidal creeks of North Inlet, a high salinity salt marsh estuary near Georgetown, South Carolina, USA, the Eastern oyster Crassostrea virginica is an abundant component of the benthic macrofauna that exerts controls on microbial communities by its grazing and nutrient regenerative activities. The effects of oyster activity on North Inlet microbial food web structure were studied using: (1) water samples collected from tidal creeks with oyster reefs versus tidal creeks without oyster reefs (removed as part of a large-scale field manipulation study); and (2) flow-through flumes. In pair-wise comparisons of creeks with similar hydrography and morphology, the only microbial group found to vary significantly with the presence of oyster reefs was the phototrophic nanoflagellates (pflags), which were 1.25- to 2.25-fold less abundant in creeks with oyster reefs during the summer phytoplankton bloom. Because heterotrophic nanoflagellates (hflags) did not vary in these same comparisons, we hypothesized that preferential feeding for pflags by oysters was responsible for the reduction in pflag abundance. The hypothesis was tested during March and July 1999 using flumes with flowing creek water containing either live oysters or dead oyster shells. Significant reductions in pflags and some types of diatoms were measured in the outflow from live oysters, but oyster effects on other microbial components (hflags, cyanobacteria, and heterotrophic bacterioplankton) were not evident. The flume study demonstrated preferential feeding by oysters on pflags using naturally occurring microbial assemblages. The differences in pflag abundance in creeks with oyster reefs versus creeks without oyster reefs suggests that this grazing activity can affect the structure of natural microbial communities.
\end{abstract}

KEY WORDS: Crassostrea virginica $\cdot$ Flume $\cdot$ Microbial food web $\cdot$ Oyster grazing $\cdot$ Phytoplankton composition · Preferential feeding $\cdot$ Tidal creek

\section{INTRODUCTION}

Studies in several different types of estuarine systems have shown that bivalve grazing can control

\footnotetext{
${ }^{*}$ Present address: 104 Ocean Administration Bldg., College of Oceanic and Atmospheric Sciences, Oregon State University, Corvallis, Oregon 97331, USA.

E-mail: mwetz@coas.oregonstate.edu
}

phytoplankton community growth and productivity (e.g. Cloern 1982, Cohen et al. 1984, Roditi et al. 1996). North Inlet estuary (near Georgetown, South Carolina, USA) is characteristic of many other salt marshes in the southeastern United States, in that the Eastern oyster Crassostrea virginica dominates the benthic macrofauna in shallow tidal creeks (Dame 1979). In examining phytoplankton trophodynamics in North Inlet, Lewitus et al. $(1998,2000)$ demonstrated that during 
the annual summer phytoplankton bloom (formed by increased abundances of nano- and picoplankton), phytoplankton population growth was not nutrient limited, but rather largely controlled by microzooplankton grazing. However, the authors did not examine the potential additional grazing impact of larger organisms, such as oysters or mussels. Previous work in North Inlet suggests that $C$. virginica could have a large impact on phytoplankton biomass (Dame et al. 1984, 1991, 1992).

Oyster feeding has been studied under laboratory conditions using phytoplankton cultures (e.g. Palmer \& Williams 1980, Shumway et al. 1985, Riisgard 1988) and natural phytoplankton assemblages (e.g. Fritz et al. 1984, Baldwin \& Newell 1991, both using oyster larvae), but rarely has it been studied in situ. The in situ observations that are available (e.g. Dame et al. $1984,1991,1992)$ are of the impact of oyster feeding on phytoplankton examined by determining changes in chlorophyll concentrations as water passes over oyster reefs, but impacts on phytoplankton composition or microbial community structure were not assessed. Studies on other bivalve species have shown an ability to affect phytoplankton community structure through their grazing activities (Riemann et al. 1988, Kemp et al. 1990, Baker et al. 1998, Noren et al. 1999, Loret et al. 2000).

Oysters can have both negative and positive influences on phytoplankton population growth through their feeding and nutrient regenerative activities. Oysters can release large amounts of ammonia and other inorganic compounds in estuarine systems (Dame et al. 1984, 1985, Dame \& Libes 1993). Thus, Dame et al. (1985) proposed the existence of a 'positive' feedback loop in which oysters graze water-column phytoplankton and subsequently release ammonia back into the water column as a byproduct of this feeding activity. Consequently, oysters may be important sources of nutrients to estuarine primary producers.

This study aimed to determine the effects of oyster grazing on North Inlet tidal creek microbial community structure in 2 ways. First, we compared chlorophyll a (chl a) concentrations, and ciliate and nanoflagellate (heterotrophic [hflag] and phototrophic [pflag]) abundances in tidal creeks with oyster reefs versus those where oyster reefs were previously removed. Subsequently, we tested the effects of oysters on natural North Inlet microbial assemblages using flowthrough flumes. The results of these experiments indicated preferential feeding by oysters on pflags.

\section{MATERIALS AND METHODS}

North Inlet is a 3200 ha high salinity salt marsh estuary located near Georgetown, South Carolina (Fig. 1). Salinities are generally greater than $32 \mathrm{psu}$, except during episodic heavy rain events. Mean tidal range is ca. $1.7 \mathrm{~m}$, with semi-diurnal tides. Flow velocities are asymmetrical with respect to tidal stage, higher on the ebbing than flooding tide, and maximal typically near mid-ebb tide. The salt marsh cordgrass Spartina
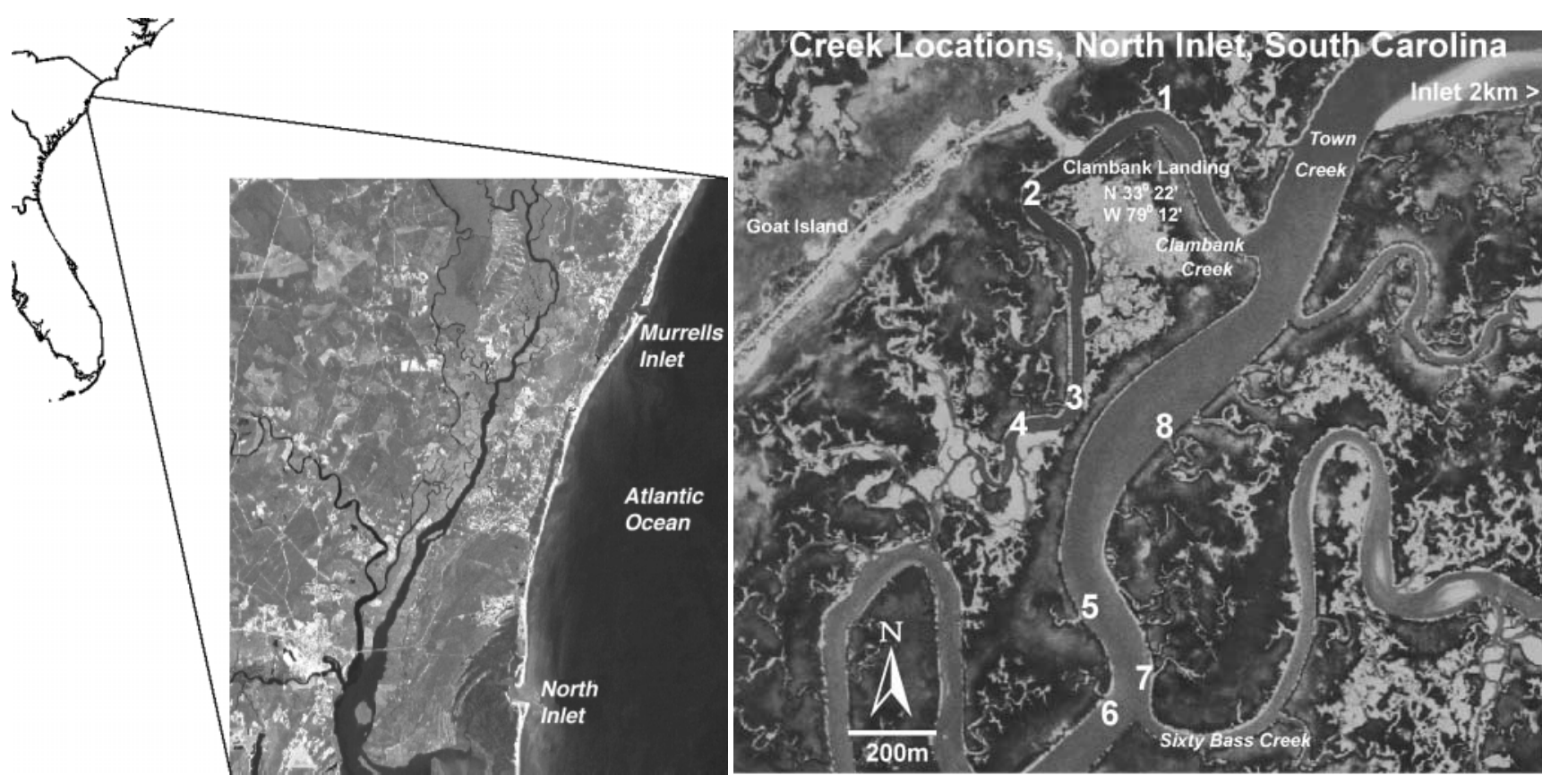

Fig. 1. Location of North Inlet estuary, near Georgetown, South Carolina, USA, showing the 8 creeks sampled in this study 
alterniflora is the dominant marshgrass in North Inlet. Crassostrea virginica is the most abundant benthic suspension feeder year-round. Biomass of $C$. virginica on intertidal oyster reefs ranges from 22 to 75 times more than that of the second most abundant suspension feeding bivalve, the scorched mussel Brachidontes exustus (Dame 1979).

Comparisons of creeks with, versus without, oyster reefs. Oyster reefs were removed from 4 North Inlet tidal creeks as part of a large-scale field manipulation experiment, the 'CREEK' project (Dame et al. 2000). In January 1997, 1 yr prior to oyster reef removal (the 'premanipulation year'), oyster biomass was normalized among 8 tidal creeks, i.e. adjusted through removal or addition (depending on the creek) to a mean creek biomass of $8 \mathrm{gdb} \mathrm{m}^{-3}$, where gdb is grams dry body weight. In February 1998, all live oysters were removed from 4 of the tidal creeks (Creeks 1, 4, 5, and 8) and left intact in 4 others (Creeks 2, 3, 6, and 7; Fig. 1). For comparative purposes, the creeks were paired (1 with and 1 without oyster reefs) based on similarities in hydrology and physical structure (i.e. Creeks 1 and 2, 3 and 4, 5 and 6, and 7 and 8); see Dame et al. (2000) for details. Replicate water samples for the present study were collected on 19 March, 17 July, and 29 August 1997 (in the pre-manipulation year), and monthly from March through September 1998 (first post-manipulation year), from the mouth of the 8 tidal creeks in the early afternoon at mid-ebb tide. Reassessment of oyster biomass in May 2000 suggested that oyster resettlement may have been pronounced during 1998 and 1999 in Creek 5 but biomass was still less than in Creek 6. In the other creeks where oyster reefs were removed (Creeks 1,4, and 8), oyster biomass remained substantially less than in the creeks where oysters were left intact (D. Bushek unpubl. data).

Water was collected in acid-cleaned 11 polycarbonate bottles at a depth of $1 \mathrm{~m}$ from the surface. Samples were then transported to the field laboratory and processed within $1 \mathrm{~h}$ of collection. Also, as part of the CREEK monitoring program, water samples were collected weekly from these same sites during mid-ebb tide. These latter samples were collected at various times of day, and only those collected in the afternoon are included here for comparative purposes.

Samples were processed for measurements of $\mathrm{NH}_{4}$ and chl a concentrations, and ciliate, pflag, and hflag abundances. $\mathrm{NH}_{4}$ concentration was determined by automated colorimetric analysis using Technicon AutoAnalyzers. Chlorophyll was extracted in $90 \%$ acetone, using a freeze-thaw method adapted from Glover \& Morris (1979). Chl a concentrations were determined fluorometrically, using a Sequoia-Turner model 450 fluorometer with NB440 excitation and SC665 emission filters. Ciliates were preserved in $3 \%$ Lugol's solu- tion and enumerated using the Utermöhl settling chamber method (Lund et al. 1958). Depending on the date collected, 50 or $100 \mathrm{ml}$ of sample was allowed to settle for ca. $1.5 \mathrm{~h}$. Ciliates were enumerated at a magnification of $300 \times$. For pflag or hflag abundance, $1 \%$ glutaraldehyde-fixed samples were stained with 4'6diamidino-2-phenylindole (DAPI), following Porter \& Feig (1980), pulled onto a $2.0 \mu \mathrm{m}$ black polycarbonate filter, and examined using an Olympus epifluorescence microscope (model BX50F) at a magnification of $600 \times$. Phototrophs and heterotrophs were differentiated by alternating between ultraviolet (DAPI fluorescence of DNA) and blue excitation (pigment autofluorescence). Duplicate ciliate and flagellate samples were counted for each data point from the 1997 study, while triplicate samples were counted for each data point from the 1998 study. Differences between paired creeks were tested for significance using $t$-tests at the $5 \%$ confidence level.

On selected dates, water collected during the monitoring program also was used in bioassay experiments to test the response of phytoplankton biomass (i.e. $\mathrm{chl}$ a) to a dilution treatment designed to reduce microzooplankton grazing pressure (Lewitus et al. 1998, modified from Landry \& Hassett 1982). Triplicate water samples from each creek were dispensed into acidcleaned $1 \mathrm{l}$ polycarbonate bottles and incubated in raceways containing flowing estuarine water. Overhead fluorescent cool white bulbs provided uniform irradiance $\left(116 \mu \mathrm{E} \mathrm{m}^{-2} \mathrm{~s}^{-1}\right)$ adjusted to a light:dark cycle simulating natural conditions $(12 \mathrm{~h}$ light:12 h dark to $14 \mathrm{~h}$ light:10 h dark, depending on sampling date). Water samples were mechanically stirred at uniform rates $(200 \mathrm{rpm})$ between bottles, using low speed AC motors with motor-post spindles driving a small paddle positioned at mid-bottle height. The flasks were time-course sampled $(24,48$, and $72 \mathrm{~h})$ for chl a concentrations. The 'dilution effect' was defined as the fractional change in chl a over $72 \mathrm{~h}$ in the whole water treatment subtracted from that in the dilution treatment (see Lewitus et al. 1998).

Flume experiment. On 19 March and 1 July 1999, 2 flow-through flumes $(8.4 \times 0.1 \mathrm{~m})$ were used to test the effects of oyster grazing on microbial community composition. Unfiltered seawater was drawn into the flumes via a pipe from Oyster Landing, a tidal creek in North Inlet. The water temperature and salinity during the experiments were $13^{\circ} \mathrm{C}$ and 34 psu respectively in March, and $28^{\circ} \mathrm{C}$ and 30 psu respectively in July. Valves on the intake pipe allowed regulation of current velocity in the flumes. Baffles were placed ca. $0.5 \mathrm{~m}$ from the intake valves in order to evenly distribute flow to the sample area. Flume 1 contained ca. 325 oyster shells alone, with no live oysters, covering an area of $0.34 \mathrm{~m}^{2}$ and served as a control that accounted 
for phytoplankton settling due to oyster shell surface area. Flume 2 was the experimental flume, containing ca. 340 live oysters. The average oyster length was $56.3 \pm 15.4 \mathrm{~mm}$ in March and $53.3 \pm 18.4 \mathrm{~mm}$ in July. Oyster biomass was determined non-destructively using the allometric equation found in Dame (1972) and is presented as shell-free dry body weight. For each trial, the average biomass was $207 \mathrm{gdb} \mathrm{m}^{-2}$. The biomass of oysters in North Inlet tidal creeks generally ranges from 200 to $250 \mathrm{gdb} \mathrm{m}^{-2}$ (Dame 1979, Dame \& Libes 1993).

Live oysters and dead shells were scrubbed several days before the experiments in order to remove attached organisms. Oysters were starved for $12 \mathrm{~h}$
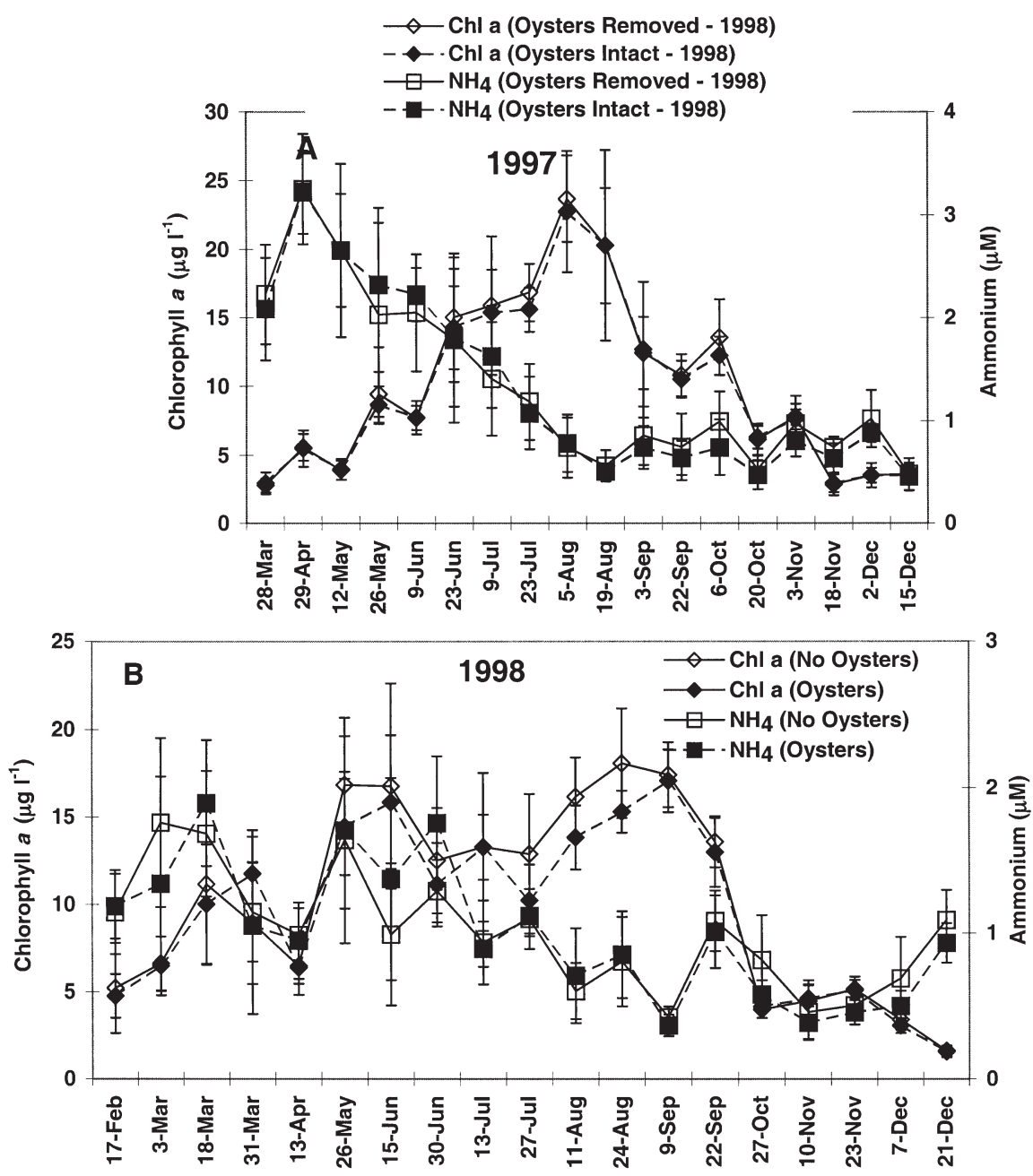

Fig. 2. Chlorophyll $a$ and ammonium concentrations from the CREEK study. (A) 1997, the 'pre-manipulation year' when oyster reef biomass was normalized between creeks. Open symbols: mean values of the 4 creeks where oyster reefs were removed in 1998; closed symbols: mean values from the 4 creeks where oyster reefs were left intact in 1998. (B) 1998, the first 'post-manipulation year'. Open symbols: mean values from the 4 creeks where oyster reefs were removed in February 1998; closed symbols: mean values from the 4 creeks where oyster reefs were left intact. Note that the axes differ with year prior to sampling. Water flow was started at high tide, with a current velocity of $10 \mathrm{~cm} \mathrm{~s}^{-1}$. The first samples were taken $1 \mathrm{~h}$ after high tide, and subsequent samples were collected every hour until $1 \mathrm{~h}$ prior to low tide, for a total of 5 sampling times. Immediately preceding each sampling time, water velocity was adjusted to correspond roughly to the in situ velocity at that tidal stage. Velocities were measured using a Marsh-Mcbirney portable water current meter (model 201D). Velocities starting with the first sampling time ere $10,20,25,15$, and $10 \mathrm{~cm} \mathrm{~s}^{-1}$, which are similar to so found in North Inlet tidal creeks over an ebbing tide cycle (Dame et. al 1985, 1992). Triplicate samples were collected from each flume simultaneously, at sites before and after passage over the oyster reefs.

Water was collected for determination of $\mathrm{NH}_{4}$ and chl a concentrations, and ciliate and flagellate abundances following the protocols above. In addition, bacterioplankton and cyanobacteria abundances were determined on $1 \%$ glutaraldehyde-fixed samples and diatom abundances on $3 \%$ Lugol'sfixed samples. Bacterioplankton were stained with acridine orange (Hobbie et al. 1977), filtered onto a $0.2 \mu \mathrm{m}$ black polycarbonate filter, and examined under blue excitation at $1000 \times$. Cyanobacteria were filtered onto a $0.2 \mu \mathrm{m}$ black polycarbonate filter and identified by autofluoresence under green excitation at $600 \times$. Diatoms were examined at a magnification of $300 \times$ using the Utermöhl settling method. Where indicated, significance is defined as $\mathrm{p}<0.05$ using $t$-tests.

\section{RESULTS}

\section{Comparison of creeks with, versus without, oyster reefs}

Annual variability was observed in the seasonal patterns of chl $a$ in 1997 and 1998, although chl a concentrations peaked in August of both years (Fig. 2). Spring chlorophyll levels were higher in 1998 than in 1997 and corresponded with relatively high $\mathrm{NH}_{4}$ concentrations. 1998 was an el Niño year that resulted in anomalously high spring rainfall and nutrient loads. The mean chl $a$ or $\mathrm{NH}_{4}$ concentration from Creeks 1, 4, 
5 , and 8 (oyster reefs removed in February 1998) and Creeks 2, 3, 6, and 7 (oyster reefs not removed) were compared in 1997 (pre-manipulation) and 1998 (postmanipulation; Fig. 2). In 1997, mean chl a concentration varied slightly between these groupings, and from May through August, chl a was on average $3.4 \pm 3.9 \%$ higher in the former group (Creeks 1, 4, 5, and 8). In 1998, the mean chl a concentration from creeks without oysters (designated 'No Oyster' creeks) averaged $13.7 \pm 8.6 \%$ higher than those with oysters (designated 'Oyster' creeks) during this same seasonal period, and $20.3 \pm 4.9 \%$ higher along the upslope of the summer bloom (27 July to 24 August), although these differences were not significant due to high between-creek variability. Also, when 1997 differences in chl a between paired creeks were taken into account (i.e. consideration of 1997 as the control year and applying the fractional difference in chl a between creek pairs in 1997 to 1998 values), the adjusted $1998 \mathrm{chl}$ a concentrations averaged $8.9 \pm 3.8 \%$ and $11.5 \pm 2.4 \%$ higher in No Oyster creeks during May through August and 27 July to 24 August, respectively (data not shown).
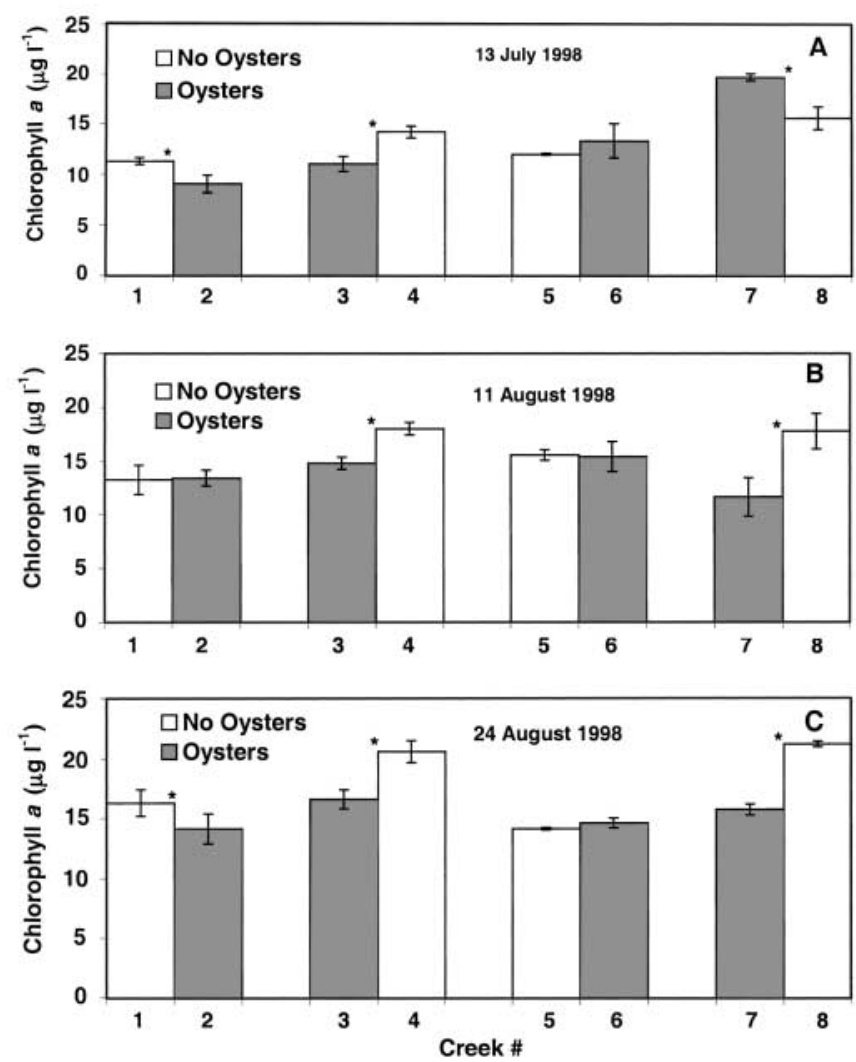

Fig. 3. Comparisons of mean chlorophyll a concentrations between paired creeks collected on dates shown. White bars: creeks where oyster reefs were removed in February 1998; grey bars: creeks where oyster reefs remained intact. *Significant difference $(\mathrm{p}<0.05)$ between means
Comparisons of chl a concentrations between paired creeks from three 1998 summer sampling periods (July/August) indicated that the means were significantly higher in 1 No Oyster creek (Creek 4) on all 3 dates (Fig. 3A-C) and in 2 other No Oyster creeks (Creeks 1 and 8) on 2 dates (Fig. 3A,C). When adjustments were made for pre-manipulation year differences in chl $a$, significant differences between creek pairs were affected in 2 cases. On 24 August, adjusted chl a concentrations between Creeks 1 and 2, and Creeks 3 and 4 were not significantly different (data not shown). The relatively higher chl a concentrations in No Oyster creeks in 1998 were not accompanied by lower $\mathrm{NH}_{4}$ concentrations, when analyzed across all creeks (Fig. 2B) or in pair-wise comparisons (data not shown).

In 1998, pflag abundance in No Oyster creeks and hflag abundance in all creeks peaked in mid-August (Fig. 4A), during the phytoplankton bloom when bacteria abundances were also maximal (E. T. Koepfler unpubl. data), while ciliate abundance was highest during July (Fig. 4B).
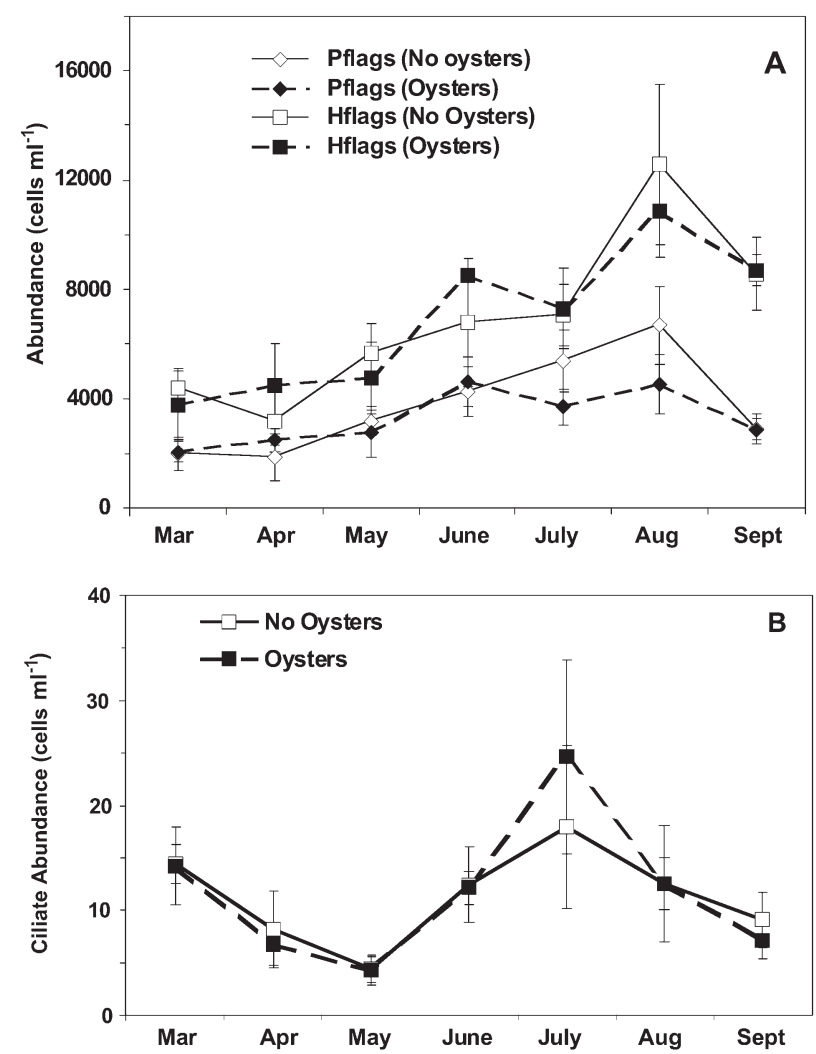

Fig. 4. (A) Phototrophic nanoflagellate (diamonds) or heterotrophic nanoflagellate (boxes) abundances and (B) ciliate abundances in 1998. Open symbols: mean abundances in the 4 creeks where oyster reefs were removed; closed symbols: mean abundances from the 4 creeks where oyster reefs were left intact 


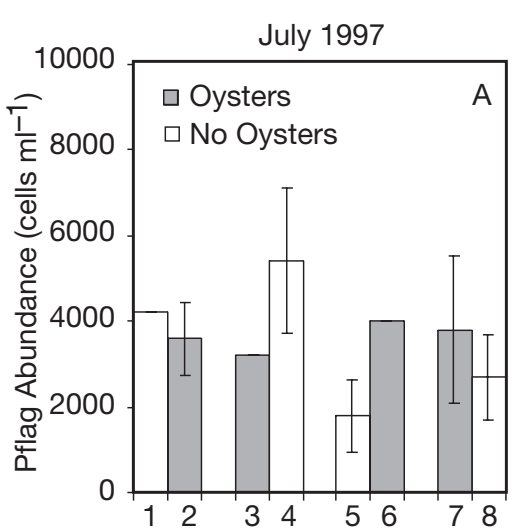

August 1997

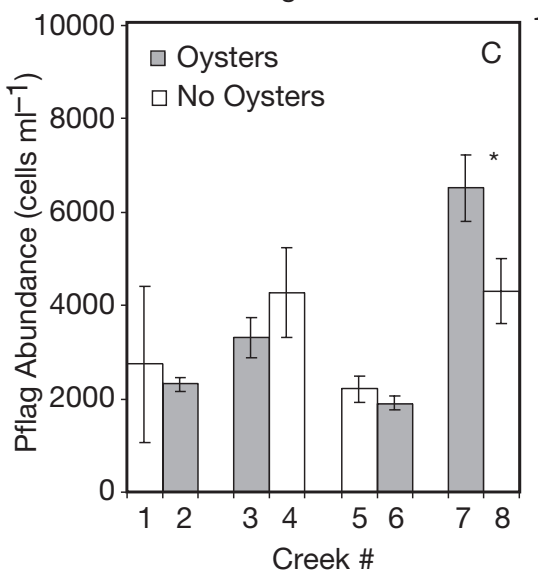

Fig. 5. Comparisons of phototrophic nanoflagellate abundances between paired creeks. White bars: values from creeks where oyster reefs were removed in February 1998; grey bars: values from creeks where oyster reefs remained intact. *Significant difference $(\mathrm{p}<0.05)$ between means

The maximum hflag abundances measured in this study $\left(>1.2 \times 10^{4}\right.$ cell ml $\left.\mathrm{m}^{-1}\right)$ are at the high end of abundances estimated from other estuarine systems (see Capriulo 1990, Sanders et al. 1992), supporting the contention that material and energy flow in the North Inlet microbial food web during the summer is strongly driven by heterotrophic processes (Lewitus et al. 1998, 2000, DeLorenzo et al. 2001).

In 1997, mean pflag abundance did not differ significantly between creek pairs during March (data not shown) or July (Fig. 5A) and only once in August (Fig. 5C). In contrast, pflags were significantly less abundant in Oyster creeks than in No Oyster creeks in all pair-wise comparisons during July 1998 (Fig. 5B) and in 2 pairs (Creek 2 versus 1; Creek 7 versus 8) in August (Fig. 5D). Also, when 1998 abundances were adjusted for pre-manipulation year differences, significant differences in abundance were still indicated in all designated comparisons with the exception of Creeks 3 and 4 in July 1998 (data not shown). By September 1998 (post-bloom period), the trend toward higher pflag abundance in No Oyster creeks was not apparent (Fig. 4A). Mean hflag abundance did not vary significantly in any creek pair comparisons in July 1998 (Fig. 6A) but was significantly different in 2 creek pairs in August 1998 (Fig. 6B), in one case higher in the No Oyster creek (Creek 1) and in the other case, in the Oyster creek (Creek 6). Mean ciliate abundance was 30.5 to $48.4 \%$ higher in the Oyster creek in 3 of the 4 creek pairings in July 1998 (Fig. 6C), but in only one case was the difference statistically significant (Creek 6). In August 1998, ciliate abundance was also significantly higher in Creek 6 (Oyster creek) than in Creek 5 (No Oyster creek), but did not differ significantly between 2 paired creeks, and was significantly higher in the No Oyster creek (Creek 1) of the other pair (Fig. 6D).

Microzooplankton grazing, as determined using a modification of the dilution method, was greatest in early August 1998 (Fig. 7A). In pair-wise comparisons, the dilution effect did not differ significantly between No Oyster and Oyster creeks (e.g. for August, Fig. 7B), consistent with the predominant lack of effect of oyster removal on hflag or ciliate abundance (Fig. 6C,D).

\section{Flume results}

Throughout the course of the flume experiment in March, total phototrophic biomass, pflag and hflag abundances were seasonally low. For example, chl a concentrations of water entering the flumes (i.e. sampled before passage through the oyster shells alone or live oysters) ranged from 0.21 to $1.04 \mathrm{\mu g} \mathrm{l}^{-1}$ (data not shown), pflag abundance from 198 to 1275 cell ml $^{-1}$, and hflag abundance from 237 to 1157 cell $\mathrm{ml}^{-1}$. These values are relatively low when compared to typical seasonal distributions (e.g. Figs. 2 \& 4A). When sampled $1 \mathrm{~h}$ after high tide and at mid-ebb tide, mean pflag abundance was significantly lower (ca. 40 to $50 \%$ ) in water collected after passage through live oysters than in water collected before passage through live oysters (Fig. 8A). No significant differences were measured in hflag abundance (Fig. 8B) or all other measured variables: chl $a_{\text {, }}$ $\mathrm{PO}_{4}$, or $\mathrm{NH}_{4}$ concentration, or heterotrophic bacterioplankton, Synechococcus sp., or diatom abundance (data not shown).

During the July flume experiment, inflow pflag (up to $6.6 \times 10^{3}$ cell ml $^{-1}$ ) and hflag (up to $16.8 \times 10^{3}$ cell $\mathrm{ml}^{-1}$ ) abundances, and chl a concentrations (up to 

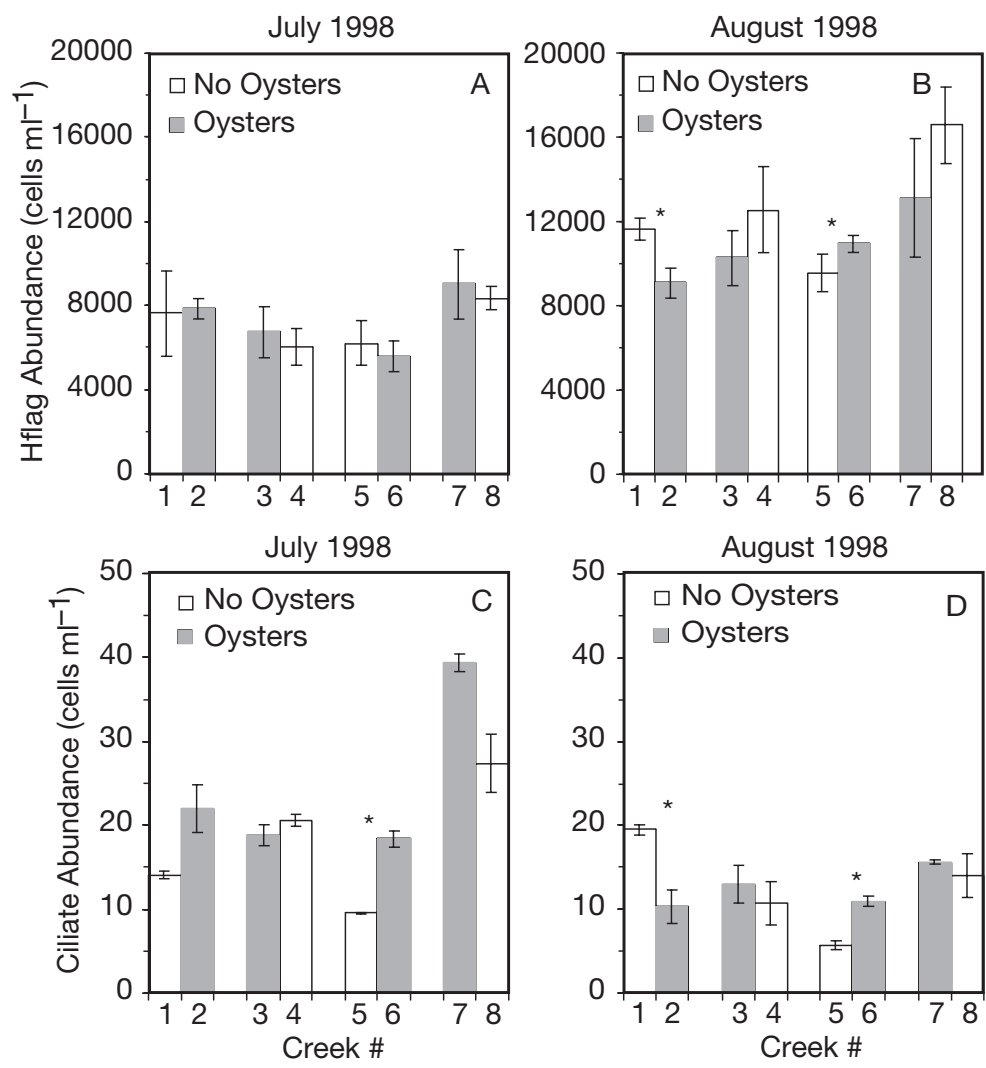

Fig. 6. Comparisons of heterotrophic nanoflagellate abundances (A,B) and of ciliate abundances $(C, D)$ between paired creeks. White bars: values from creeks where oyster reefs were removed in February 1998; grey bars: values from creeks where oyster reefs remained intact. *Significant difference $(\mathrm{p}<0.05)$ between means

$15 \mu \mathrm{g} \mathrm{l}^{-1}$ ) were much higher than in March and typical of summertime bloom conditions (e.g. Figs. 2 \& 4A). At 1 and $5 \mathrm{~h}$ after high tide (times of relatively low flow velocity), mean pflag abundance after passage through live oysters was significantly lower (ca. 25 to $50 \%$ ) than that in the other flume areas sampled (Fig. 9A), while hflag abundance did not vary significantly in the presence of live oysters at any time point (Fig. 9B). Although an effect of live oysters on diatom abundances was at times apparent, high variability in these estimates made it difficult to discern any clear trends, and these data are not presented here. Significantly lower mean chl a concentrations were measured in the presence of live oysters at $1 \mathrm{~h}$ after high tide (Fig. 10A) and at mid-ebb tide. An apparent effect of live oysters on increasing $\mathrm{NH}_{4}$ concentration was observed at 2, 3, and $4 \mathrm{~h}$ after high tide (Fig. 10B). In contrast, $\mathrm{PO}_{4}$ concentrations and the abundances of other microbial groups (e.g. heterotrophic bacterioplankton, Synechococcus sp.) never varied significantly ( $t$-test, $\mathrm{p}<0.05$ ) between sampling areas (data not shown).

\section{DISCUSSION}

Comparisons of microbial communities from tidal creeks with, versus without, oyster reefs and direct examination of oyster grazing in flume experiments indicate an effect of oyster reefs on microbial community composition, and suggest preferential feeding by oysters on pflags. The presence of oyster reefs (in the field tidal creek comparisons) or live oysters (in the flume study) often resulted in lower abundances of pflags but did not affect the abundance of hflags, ciliates, heterotrophic bacterioplankton, or cyanobacteria. Based on the similar effects of the field manipulation and flume experiments, the impact of oyster reefs on microbial community composition in these tidal creeks may be attributed largely to the direct effects of oyster grazing, although the additional influence of microbial processing by other oyster reef-associated invertebrates can-
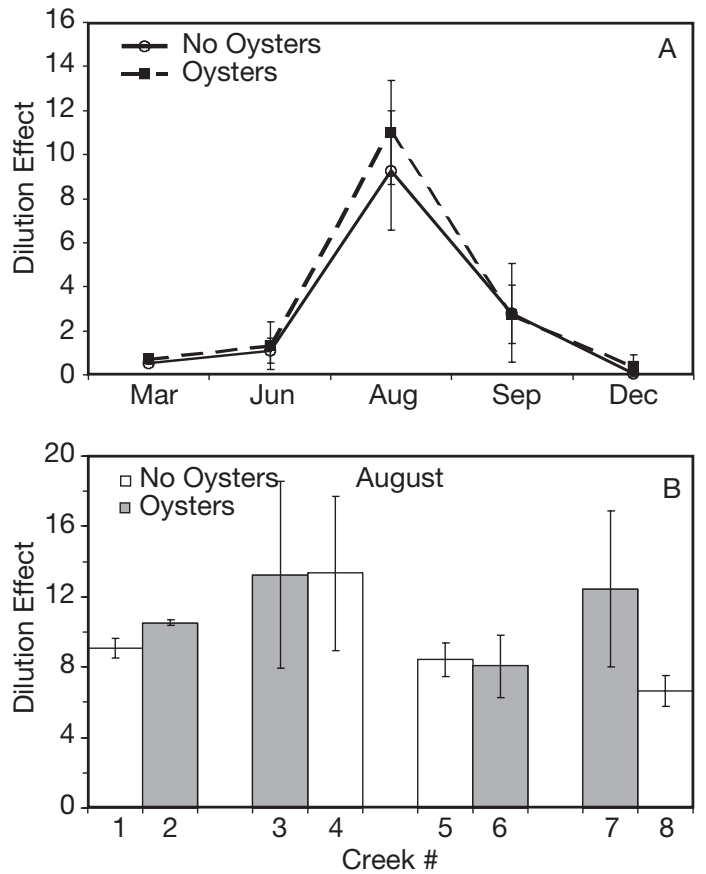

Fig. 7. Dilution experiment effect during 1998, the first 'postmanipulation' year. (A) Monthly mean values. (—) Mean values from the 4 creeks where oyster reefs were removed in February 1998; (--- -) mean values from the 4 creeks where oyster reefs were left intact. (B) Comparison of dilution effect between paired creeks on 3 August 1998. White bars: values from creeks where oyster reefs were removed; grey bars: values from creeks where oyster reefs were left intact. Dilution values represent the mean $(n=3)$ fractional difference between observed abundances in dilution bottles, and predicted abundances if the rate of change in dilution bottles over $72 \mathrm{~h}$ were equivalent to that of whole water control bottles 

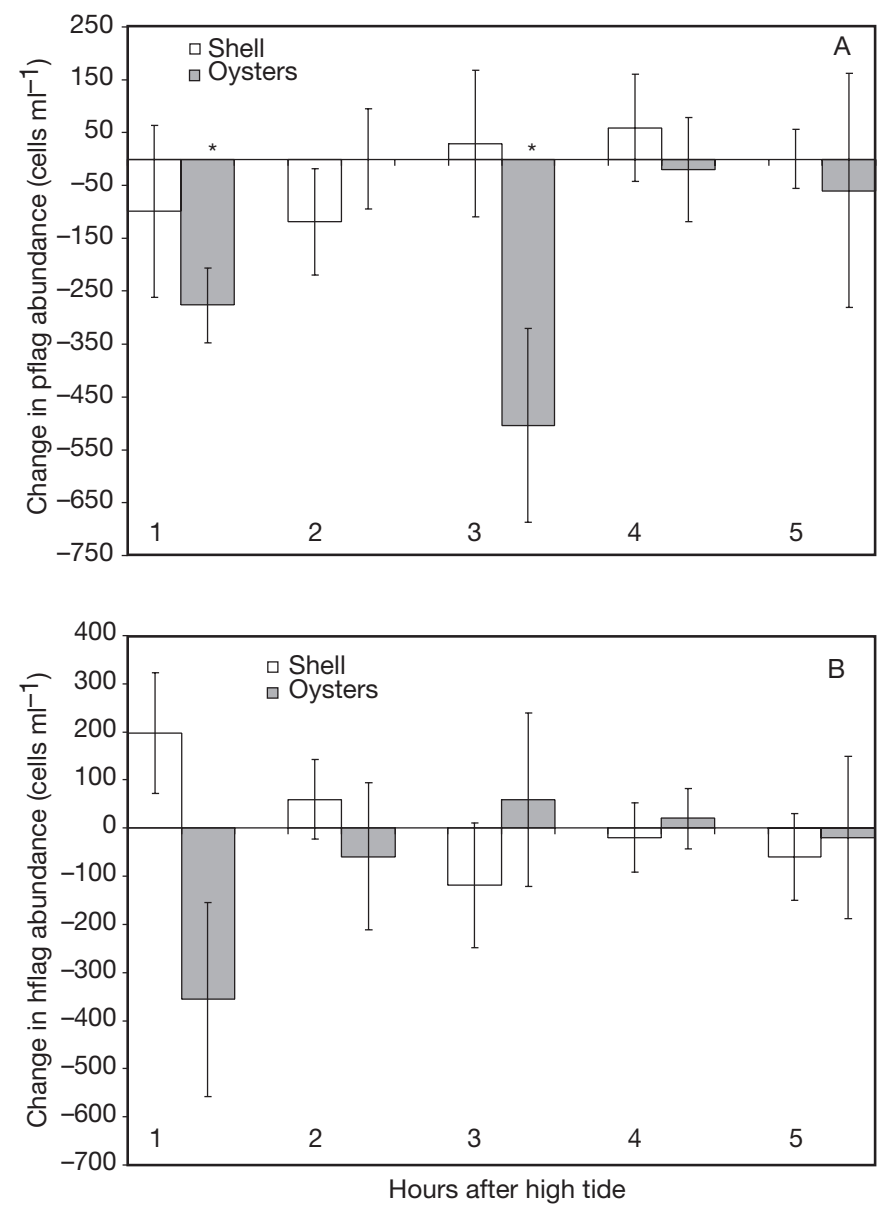

Fig. 8. Change in (A) phototrophic nanoflagellate and (B) heterotrophic nanoflagellate abundances during March flume experiment, measured over the course of the ebbing tide, from sites with oyster shells alone (white bars) or live oysters (grey bars). *Significant change $(\mathrm{p}<0.05)$

not be discounted. The possibility that oyster filtration can influence North Inlet microbial communities on relatively short time scales is supported by Dame et al.'s (1980) estimate that oysters can filter ca. $1.5 \times 10^{7}$ $\mathrm{m}^{3}$ of water out of a total tidal prism of $2.2 \times 10^{7} \mathrm{~m}^{3}$.

In North Inlet, the summer phytoplankton bloom forms as a result of increased abundances of phototrophic pico- and nanoflagellates (Lewitus et al. 1998, 2000). During this period, microzooplankton grazing predominates over nutrient limitation in the regulation of phytoplankton population growth, and regenerated nutrients (e.g. $\mathrm{NH}_{4}$, dissolved organic nitrogen [DON]) are the major nitrogen sources supporting pflag growth. Hypothesized sources of regenerated nitrogen include microzooplankton and oysters (Lewitus et al. 1998, 2000, Dame et al. 2000, 2002). In the present study, the flume experimental results demonstrated an effect of live oysters on increasing $\mathrm{NH}_{4}$ concentrations at certain tidal stages. Although these results indicate a potential for production of $\mathrm{NH}_{4}$ by oyster activity (e.g. Dame et al. 1984, 1985, Dame \& Libes 1993), this effect was not evident in the tidal creek comparisons; i.e. $\mathrm{NH}_{4}$ concentrations between creeks with and without oyster reefs were not significantly different (Dame et al. 2002, this study). Overall, the net impact of oyster reef removal was increased phytoplankton biomass but not decreased $\mathrm{NH}_{4}$ levels, suggesting that in North Inlet tidal creeks, alternative sources of $\mathrm{NH}_{4}$ can compensate for loss of oyster excretory products, but that oyster filtration may be a more essential factor for regulating phytoplankton population growth.

As expected, a seasonal trend in oyster feeding activity was observed. Although some grazing on flagellates occurred in the March flume experiment with oysters, the magnitude of the grazing effect was much less (3- to 5-fold) than in July. Relatively lower grazing in March may have been a function of the lower metabolic needs of oysters at lower water
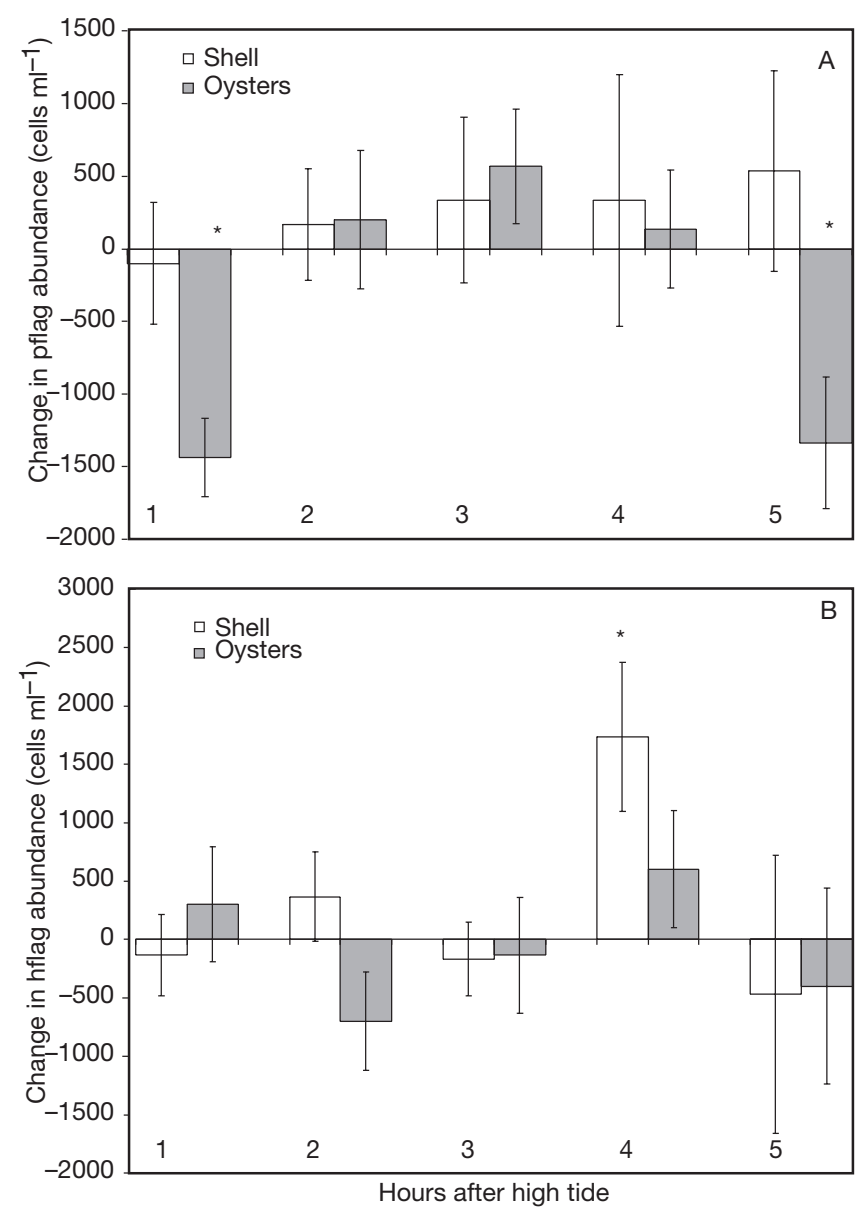

Fig. 9. Change in (A) phototrophic nanoflagellate and (B) heterotrophic nanoflagellate abundances during July flume experiment, measured over the course of the ebbing tide, from sites with oyster shells alone (white bars) or live oysters (grey bars). *Significant change $(\mathrm{p}<0.05)$ 

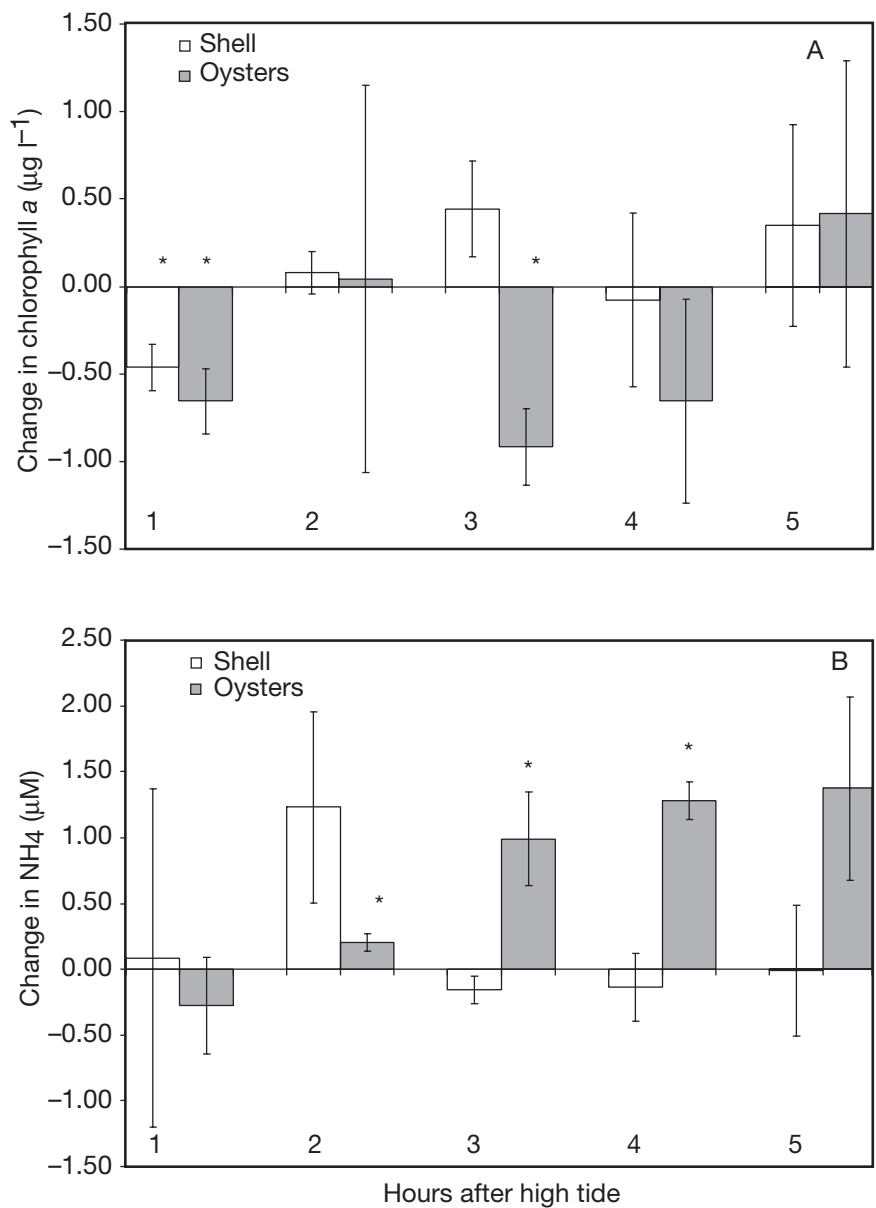

Fig. 10. Change in (A) chlorophyll $a$ and (B) ammonium concentrations during July flume experiment, measured over the course of the ebbing tide, from sites with oyster shells alone (white bars) or live oysters (grey bars). *Significant change $(\mathrm{p}<0.05)$

temperatures or lower particle concentrations. Loosanoff (1958) demonstrated maximal pumping rates for oysters at water temperatures near $29^{\circ} \mathrm{C}$ and much lower rates at $13^{\circ} \mathrm{C}$. Also, clearance rates of oysters vary with particle concentration and can rapidly increase above specific thresholds (see Newell \& Langdon 1996). Despite the fact that grazing on pflags was evident only at the lowest flow velocities in the July flume experiments (within $1 \mathrm{~h}$ of slack tides), a cumulative and potentially pronounced impact of oyster grazing on phytoplankton community structure and biomass in the summer was suggested in the pair-wise creek comparisons, in which chl a concentration and pflag abundance were generally higher in creeks without oyster reefs.

Because hflags were generally more abundant than pflags in our study, it is likely that the latter are a preferred food source for the oysters and were selected over the heterotrophs. Several characteristics of food items have been proposed as benchmarks that bivalves may rely on during the particle selection process, including prey size and chemical composition (Loosanoff 1949, Newell \& Jordan 1983, Newell et al. 1989, Ward \& Targett 1989). The observation that heterotrophic bacterioplankton and Synechococcus sp. did not vary with sampling location in the flumes is consistent with the conclusions of previous studies that oyster filtration efficiency is greatly reduced below a prey size of 3 to $5 \mu \mathrm{m}$ (Haven \& Morales-Alamo 1970, Palmer \& Williams 1980, Riisgaard 1988, Langdon \& Newell 1990). However, size discrimination cannot account for the selective effect on pflag prey because the size range of this group was similar to that of hflags (between 4 and $15 \mu \mathrm{m}$ ). Therefore, unless the motility of the 2 flagellate types differs, selection based on chemical characteristics of the cells must be strongly considered.

Phytoplankton-derived dissolved metabolites (Hellebust 1974), such as amino acids, fatty acids, sugars, and other compounds, are known to influence bivalve feeding activity (Davids 1964, Ali 1970, Morton 1971, Ward \& Targett 1989, Targett \& Ward 1991), although the effects can vary with bivalve species. For instance, Ward \& Targett (1989) found that dissolved metabolites from several different species of microalgae reduced the filtration rate of Mytilus edulis, but Ward et al. (1992) found that metabolites from the diatom Chaetoceros muelleri stimulated clearance and ingestion rates in the sea scallop Placopecten magellanicus. A similar role of dissolved metabolites from pflags stimulating feeding activity in Crassostrea virginica is a possible explanation for our observations of preferential feeding on the pflags.

Although the role of chemical cues in regulating the feeding rate of Crassotrea virginica is unknown, there is strong evidence that oysters rely on chemical cues in sorting particles. Newell \& Jordan (1983) showed that oysters are able to preferentially ingest organic particles and reject other particles as pseudofeces. They proposed that this behavior was facilitated by a chemoreceptive ability in oysters. Bougrier et al. (1997) also observed high pre-ingestive selection of several species of flagellates over diatoms by C. gigas. Because the flagellates and diatoms were of similar size, the authors speculated that the diatoms may have appeared as mineral particles due to their frustules and were thus rejected as pseudofeces. In contrast to the above, Shumway et al. (1985) saw no pre-ingestive selection by $C$. virginica but did find strong evidence for post-ingestion, preferential digestion of the cryptophyte Chroomonas salina in mixed diets with the diatom Phaeodactylum tricornutum and the dinoflagellate Prorocentrum minimum. On the basis of the 
results of their study, Shumway et al. (1985) suggested that certain microorganisms might be more important to the diet of bivalves than their relative abundance in nature might suggest. The field study of Loret et al. (2000) showed that the pearl oyster Pinctada margaritifera preferentially ingested cryptophytes over more abundant microalgal types. Therefore, it appears that these observations also apply to our study where pflags were selected over the numerically dominant hflags, suggesting that the former are likely a preferred food source for oysters.

It is known that oysters are substantial grazers of planktonic organisms, particularly phytoplankton, but information is lacking on oyster dietary preferences in nature and the regulatory mechanisms behind their feeding activity. Our results suggest that oysters in North Inlet tidal creeks show a strong preference for pflags over hflags and can affect phytoplankton biomass, emphasizing their role in regulating microbial food web structure and primary productivity in this and other estuaries where oysters are prominent components of the benthic macrofauna.

Acknowledgements. We wish to thank the Honors Program and Marine Science Department of Coastal Carolina University, and the numerous Coastal Carolina University students who helped with the CREEK project. M.S.W. and K.C.H. would like to thank Dr. Susan Libes for her guidance and support during this project. Thanks to Don Caton, Rick Matthews, and Paul Kenny of the University of South Carolina's Baruch Marine Laboratory for their help in construction of the flumes, to Bonnie Willis, Ivy Collins, Raphael Tymowski, Emily Butsic, and Beth Brost for their help with the flume sampling, and to Ryan Pigg and Leah Gregory for assistance in field collections. We are also grateful to David Bushek, Richard Dame, Donald Edwards, and Chris Corbett for supplying advice and essential information based on their collaborative efforts during the CREEK project. Finally, we wish to thank 3 anonymous reviewers for their constructive suggestions, which improved this manuscript. The research was funded by the National Science Foundation's Research Experience for Undergraduates (REU) Program, grant DEB9509057, the US ECOHAB Program, sponsored by NOAA/NSF/EPA/NASA/ONR, grant NA86OP0493, NOAA grant NA90AA-D-SG672, and EPA grant R826944-01-0. Contribution No. 1347 of the Belle W. Baruch Institute for Marine Biology and Coastal Research. ECOHAB Contribution No. 48.

\section{LITERATURE CITED}

Ali RM (1970) The influence of suspension density and temperature on the filtration rate of Hiatella arctica. Mar Biol 6:291-302

Baker SM, Levinton JS, Kurdziel JP, Shumway SE (1998) Selective feeding and biodeposition by zebra mussels and their relation to changes in phytoplankton composition and seston load. J Shellfish Res 17:1207-1213

Baldwin BS, Newell RIE (1991) Omnivorous feeding by the planktotrophic larvae of the eastern oyster Crassostrea virginica. Mar Ecol Prog Ser 78:285-301
Bougrier S, Hawkins AJS, Héral M (1997) Preingestive selection of different microalgal mixtures in Crassostrea gigas and Mytilus edulis analyzed by flow cytometry. Aquaculture 150:123-134

Capriulo GM (1990) Feeding-related ecology of marine protozoa. In: Capriulo GM (ed) Ecology of marine protozoa. Oxford University Press, New York, p 186-259

Cloern JE (1982) Does the benthos control phytoplankton biomass in south San Francisco Bay? Mar Ecol Prog Ser 9: 191-202

Cohen RRH, Dresler PV, Phillips EJP, Cory RL (1984) The effect of the Asiatic clam, Corbicula fluminea, on phytoplankton of the Potomac River, Maryland. Limnol Oceanogr 29:170-180

Dame RF (1972) Comparison of various allometric relationships in intertidal and subtidal American oysters. Fish Bull 70:1121-1126

Dame RF (1979) The abundance, diversity and biomass of macrobenthos on North Inlet, South Carolina, intertidal oyster reefs. Proc Natl Shellfish Assoc 69:6-10

Dame R, Libes S (1993) Oyster reefs and nutrient retention in tidal creeks. J Exp Mar Biol Ecol 171:251-258

Dame R, Zingmark R, Stevenson L, Nelson D (1980) Filter feeder coupling between the estuarine water column and benthic subsystems. In: Kennedy VC (ed) Estuarine perspectives. Academic Press, New York, p 521-526

Dame RF, Zingmark RG, Haskin E (1984) Oyster reefs as processors of estuarine materials. J Exp Mar Biol Ecol 83:239-247

Dame RF, Wolaver TG, Libes SM (1985) The summer uptake and release of nitrogen by an intertidal oyster reef. Neth J Sea Res 19:265-268

Dame RF, Spurrier JD, Williams TM, Kjerfve B and 5 others (1991) Annual material processing by a salt marshestuarine basin in South Carolina, USA. Mar Ecol Prog Ser 72:153-166

Dame RF, Spurrier JD, Zingmark RG (1992) In situ metabolism of an oyster reef. J Exp Mar Biol Ecol 164:147-159

Dame R, Bushek D, Allen D, Edwards D and 7 others (2000) The experimental analysis of tidal creeks dominated by oyster reefs: the premanipulation year. J Shellfish Res 19: 361-369

Dame R, Bushek D, Allen D, Lewitus A, Edwards D, Koepfler E, Gregory L (2002) Ecosystem response to bivalve density reduction: management implications. Aquat Ecol 36: 51-65

Davids C (1964) The influence of suspensions of microorganisms of different concentrations on the pumping and retention of food by the mussel (Mytilus edulis L.). Neth J Sea Res 2:233-249

DeLorenzo ME, Lewitus AJ, Scott GI, Ross PE (2001) Use of metabolic inhibitors in assessing the structure and function of an estuarine microbial food web. Microb Ecol 42: $317-327$

Fritz LW, Lutz RA, Foote MA, Van Dover CL, Ewart JW (1984) Selective feeding and grazing rates of oyster (Crassostrea virginica) larvae on natural phytoplankton assemblages. Estuaries 7:513-518

Glover HE, Morris I (1979) Photosynthetic carboxylating enzymes in marine phytoplankton. Limnol Oceanogr 23: $510-519$

Haven D, Morales-Alamo R (1970) Filtration of particles from suspension by the American oyster, Crassostrea virginica. Biol Bull 139:248-264

Hellebust JA (1974) Extracellular products. In: Stewart WDP (ed) Algal physiology and biochemistry. Blackwell Scientific Publications, Oxford, p 838-863 
Hobbie JE, Daley RJ, Jasper S (1977) Use of Nucleopore filters for counting bacteria by fluorescence microscopy. Appl Environ Microbiol 33:1225-1228

Kemp PF, Newell SY, Krambeck C (1990) Effects of filterfeeding by the ribbed mussel Geukensia demissa on the water-column microbiota of a Spartina alterniflora saltmarsh. Mar Ecol Prog Ser 59:119-131

Landry MR, Hassett RP (1982) Estimating the grazing impact of marine microzooplankton. Mar Biol 67:283-288

Langdon CJ, Newell RIE (1990) Utilization of detritus and bacteria as food sources by two bivalve suspension feeder, the oyster Crassostrea virginica and the mussel Geukensia demissa. Mar Ecol Prog Ser 58:299

Lewitus AJ, Koepfler ET, Morris JT (1998) Seasonal variation in the regulation of phytoplankton by nitrogen and grazing in a salt-marsh estuary. Limnol Oceanogr 43:636-646

Lewitus AJ, Koepfler ET, Pigg RJ (2000) Use of dissolved organic nitrogen by a salt marsh phytoplankton bloom community. Arch Hydrobiol Spec Issue Adv Limnol 55: 441-456

Loosanoff VL (1949) On the food selectivity of oysters. Science 110:122

Loosanoff VL (1958) Some aspects of behavior of oysters at different temperatures. Biol Bull 114:57-70

Loret P, Pastoureaud A, Bacher C, Delesalle B (2000) Phytoplankton composition and selective feeding of the pearl oyster Pinctada margaritifera in the Takapoto lagoon (Tuamotu Archipelago, French Polynesia): in situ study using optical microscopy and HPLC pigment analysis. Mar Ecol Prog Ser 199:55-67

Lund JWG, Kipling C, LeCren ED (1958) The inverted microscope method of estimating algal numbers and the statistical basis of estimates by counting. Hydrobiologia 11: $143-170$

Morton B (1971) Studies on the biology of Dreissena polymorpha Pall. V. Some aspects of filter-feeding and the effect of microorganisms upon the rate of filtration. Proc Malacol Soc Lond 39:289-301

Newell RIE, Jordan SJ (1983) Preferential ingestion of organic material by the American oyster Crassostrea virginica. Mar Ecol Prog Ser 13:47-53

Newell RIE, Landgon CJ (1996) Mechanisms and physiology of larval and adult feeding. In: Kennedy VS, Newell RIE,

Editorial responsibility: David Caron,

Los Angeles, California, USA
Eble AF (eds) The eastern oyster Crassostrea virginica. Maryland Sea Grant, College Park, p 185-229

Newell CR, Shumway SE, Cucci TL, Selvin R (1989) The effects of natural seston particle size and type on feeding rates, feeding selectivity and food resource availability for the mussel Mytilus edulis L. at bottom culture sites in Maine. J Shellfish Res 8:187-196

Noren F, Haamer J, Lindahl O (1999) Changes in the plankton community passing a Mytilus edulis mussel bed. Mar Ecol Prog Ser 191:187-194

Palmer RE, Williams LG (1980) Effect of particle concentration on filtration efficiency of the bay scallop Argopecten irradians and the oyster Crassostrea virginica. Ophelia 19: 163-174

Porter KG, Feig Y (1980) The use of DAPI for identifying and counting aquatic microflora. Limnol Oceanogr 25:943-948

Riemann B, Nielson TG, Horsted ST, Bjornsen PK, Pock-Steen J (1988) Regulation of phytoplankton biomass in estuarine enclosures. Mar Ecol Prog Ser 48:205-215

Riisgard HU (1988) Efficiency of particle retention and filtration rate in 6 species of northeast American bivalves. Mar Ecol Prog Ser 45:217-223

Roditi HA, Caraco NF, Cole JJ, Strayer DL (1996) Filtration of Hudson River water by the zebra mussel (Dreissena polymorpha). Estuaries 19:824-832

Sanders RW, Caron DA, Berninger UG (1992) Relationships between bacteria and heterotrophic nanoplankton in marine and fresh waters: an inter-ecosystem comparison. Mar Ecol Prog Ser 86:1-14

Shumway SE, Cucci TL, Newell RC, Yentsch CM (1985) Particle selection, ingestion, and absorption in filter-feeding bivalves. J Exp Mar Biol Ecol 91:77-92

Targett NM, Ward JE (1991) Bioactive microalgal metabolites: mediation of subtle ecological interactions in phytophagous suspension-feeding marine invertebrates. Bioorg Mar Chem 4:91-118

Ward JE, Targett NM (1989) Influence of marine microalgal metabolites on the feeding behavior of the blue mussel Mytilus edulis. Mar Biol 101:313-321

Ward JE, Cassell HK, Macdonald BA (1992) Chemoreception in the sea scallop Placopecten magellanicus (Gmelin). I. Stimulatory effects of phytoplankton metabolites on clearance and ingestion rates. J Exp Mar Biol Ecol 163:235-250

Submitted: July 16, 2001; Accepted: March 4, 2002

Proofs received from author(s): May 10, 2002 